\title{
PENGARUH PEMBINAAN DAN PENGEMBANGAN KARIR TERHADAP KINERJA PEGAWAI
}

\author{
Aep Ahmad Saehu ${ }^{1}$ \\ ${ }^{1}$ Program Studi Manajemen Pascasarjana Universitas Galuh Ciamis \\ email: aepahmadsaehu@gmail.com
}

\author{
Article History : \\ Received 20 August 2018 \\ Recieved in revished form \\ 27 September 2018 \\ Acepted 8 October 2018 \\ Available offline 29 October 2018 \\ Available online 29 October 2018
}

Language Transcript :

Indonesia(id)

Key Words :

Pembinaan

PengembanganKarir

Kinerja Pegawai

\begin{abstract}
Tujuan penelitian ini adalah untuk mengetahui Pengaruh Pembinaan Terhadap Kinerja Pegawai, Pengaruh Pengembangan Karir Terhadap Kinerja Pegawai, dan Pengaruh Pembinaan dan Pengembangan Karir Terhadap Kinerja Pegawai pada Dinas Ketahanan Pangan, Pertanian dan Perikanan Kota Banjar. Dalam penelitian ini penulis menggunakan metode penelitian kuantitatif (Quantitative Research). Metode kuantitatif adalah rancangan penelitian meliputi pemilihan subjek, teknik pengumulan data (seperti kuesioner, obsrervasi dan wawancara). Dengan skala ukur yang digunakan dalam penelitian ini adalah Likert. Dengan teknik pengambilan sampel menggunakan teknik total sampling. Jadi sampel yang akan digunakan sebanyak 52 orang. Berdasarkan penelitian tentang Pengaruh Pembinaan dan Pengembangan karir Terhadap Kinerja pegawai pada Dinas Ketahanan pangan, Pertanian dan Perikanan Kota Banjarmenunjukanhasilbahwa : Terdapat pengaruh pembinaan terhadap kinerja pegawai artinya bahwa semakin baik pembinaan di dalam instansi maka kinerja pegawai akan semakin meningkat. Terdapat pengaruh pengembangan karir terhadap kinerja pegawai artinya semakin baik pengembangan karir maka kinerja pegawai akan semakin meningkat. Terdapat pengaruh pembinaan dan pengembangan karir terhadap kinerja pegawai artinya semakin baik pembinaan dan pengembangan karir maka kinerja pegawai akan semakin meningkat.
\end{abstract}

\section{PENDAHULUAN}

Keberhasilan suatu organisasi sangat dipengaruhi oleh kinerja individu pegawainya. Setiap organisasi akan selalu berusaha untuk meningkatkan kinerja pegawai, dengan harapan apa yang menjadi tujuan dan visi organisasi akan tercapai. Kinerja pegawai menurut Mangkunegara (2009: 9) menyatakan bahwa "Kinerja karyawan adalah hasil kerja secara kualitas dan kuantitas yang dicapai oleh seorang karyawan dalam melaksanakan tugasnya sesuai dengan tanggungjawab yang diberikan kepadanya". Kinerja PNS merupakan cerminan perilaku dan kemampuan PNS dalam melaksanakan tugas yang dibebankan kepadanya. Tinggi rendahnya kinerja PNS dapat dipengaruhi oleh berbagai faktor, diantaranya adalah pembinaan dan pengembangan karir.

Pembinaan terhadap sumber daya manusia sangat dibutuhkan dalam peningkatan kualitas kinerja, pembinaan terhadap Pegawai Negri Sipil bertujuan untuk meningkatkan disiplin, mengembangkan karir dan etika mereka.

Optimalisasi peningkataan kinerja PNS suatu instansi pemerintah dapat terwujud 
apabila instansi tersebut berkewajiban melaksanakan program pengembangan karir bagi pegawainya. Menurut Sudiro (2011:91). Pengembangan karier adalah proses peningkatan kemampuan kerja individu yang dicapai dalam rangka mencapai karier yang diinginkan. Pengembangan karier merupakan suatu kondisi yang menunjukkan adanya sebuah peningkatan-peningkatan status seseorang pada suatu organisasi dalam jalur karier yang telah ditetapkan dalam organisasi yang bersangkutan. (Dwi Wahyuni, Hamidah Nayati dan Ika Ruhana, dalam http://download.portalgaruda.org/article.)

Pembinaan dan pengembangan karir bagi pegawai negeri sipil merupakan suatu keharusan sekaligus hak mereka sebagai PNS, dengan adanya pembinaan yang optimal dan pengembangan karir yang jelas dapat memberikan efek positif bagi PNS, diantaranya timbulnya motivasi kerja yang tinggi sehingga berdampak pada etos kerja dan peningkatan kinerja mereka.

Akan tetapi berdasarkan kondisi nyata dilapangan masih terdapat pembinaan yang kurang optimal di Dinas Ketahanan pangan, Pertanian dan Perikanan yang tercermin pada disiplin kerja pegawai yang masih sangat kurang. Diantaranya masih ditemukannya pegawai yang tidak ada di tempat disaat jam kerja.

Selain itu dalam pengembangan karir, masih ditemukannya system politisasi dalam pengangkatan jabatan struktural, maka dalam proses promosi kurang mendasarkan pada kompetensi nyata para calon yang akan diangkat sehingga masih ditemukannya pejabat yang kurang kompeten dibidangnya.

Akibat dari system pengembangan karir yang kurang jelas dan kurang objektif tersebut menimbulkan ekses negative bagi kinerja pegawai negri sipil di tingkat pelaksana, hal ini tampak dari beberapa indikitor masalah yang ditemukan di Dinas
Ketahanan Pangan, Pertanian dan Perikanan Kota Banjar diantaranyas ebagai berikut : (1) Kualitas pegawai masih rendah, (2) Kerjasama antar pegawai masih rendah.

Berdasarkan fakta, fenomena dan permasalahan diatas, dipandang perlu untuk melakukan kajian yang lebih lanjut terhadap pembinaan dan pengembangan karir di DKPPP Kota Banjar serta pengaruhnya terhadap kinerja pegawai Dinas Ketahanan Pangan, Pertanian dan Perikanan Kota Banjar.

\section{METOOLOGI}

Penelitian yang digunakan adalah penelitian penjelasan (explanatory research), ebagaimana yang dikatakan oleh Burhan (2008:38) penelitian penjelasan (explanatory research) dimaksud untuk menjelaskan suatu generalisasi sampel terhadap populasinya atau menjelaskan hubungan, perbedaan, atau pengaruh satu variabel dengan variabel lain. Penelitian ini akan diketahui apakah ada pengaruh yang signifikan antara variabel pembiaan dan pengembangan karir terhadap kinerja pegawai Dinas Ketahanan pangan, Pertanian dan Perikanan Kota Banjar sebanyak 52 pegawai.

\section{HASIL DAN PEMBAHASAN}

\subsection{Pengaruh Pembinaan dan Pengembangan karir terhadap Kinerja pegawai}

Dari hasil penelitian membuktikan bahwa pembinaan dan pengembangan karir memiliki pengaruh yang positif dan signifikan terhadap kinerja pegawai Dinas Ketahanan Pangan, Pertanian dan Perikanan Kota Banjarartinya semakin baik pembinaan dan pengembangan karir maka kinerja pegawai akan semakin meningkat, namum sebaliknya jika pembinaan dan pengembangan karir rendah, maka akan semakin rendah pula kinerja pegawai pada 
Dinas Ketahanan Pangan, Pertanian dan Perikanan Kota Banjar.

Hasil analisis penelitian ini sejalan dengan pendapat Munir (1994: 152) mengungkapkan bahwa Pembinaan Pegawai adalah usaha yang perlu dilakukan oleh pimpinan dalam meningkatkan prestasi kerja agar dapat melaksanakan tugas secara efektif dan efisien. Semakin kuat pembinaan dan pengembangan karir yang dilaksanakan maka motivasi, kemampuan dan hasil kerja pegawai dapat meningkat, sebaliknya apabila pembinaan dan pengembangan karir yang lemah dapat menurunkan motivasi, kemampuan dan hasil kerja PNS pada suatu instansi.

\subsection{Pengaruh Pengembangan karir terhadap Kinerja pegawai}

Pengembangan karir memiliki pengaruh yang positif dan signifikan terhadap kinerja pegawai pada Dinas Ketahanan Pangan, Pertanian dan Perikanan Kota Banjar, artinya bahwa semakin baik pengembangan karir di dalam organisasi maka kinerja pegawai akan semakin meningkat.

Hasil analisis penelitian ini sejalan dengan pendapat (Harlie, 2012) yang menyatakan bahwa pengembangan karir berpengaruh nyata secara parsial terhadap kinerja. Ketika Pegawai Negeri Sipil sudah tidak memikirkan gaji tapi lebih ke prestice yang dimana sebagai Pegawai Negeri Sipil akan menduduki pangkat atau jabatan tertentu dalam dinas maka karir pegawai semakin tinggi, kekuasan dan pendidikan juga semakin tinggi maka pengetahuannya pun makin bertambah. Semakin tinggi pengembangan karir maka kinerja pegawai akan meningkat. Meskipun pendidikan formal sangat berpengaruh positif, disisi lain pelatihan, konseling dan kontrol juga sangat penting dalam meningkatkan loyalitas pegawai dan mengurangi kecurangan-kecurangan dalam melaksanakan tugas (Darna, Rosliyati, Herlina, 2015).

\subsection{Pengaruh Pembinaan terhadap Kinerja pegawai}

Pembinaan memiliki pengaruh yang positif dan signifikan terhadap kinerja pegawai pada Dinas Ketahanan Pangan, Pertanian dan Perikanan Kota Banjar, artinya bahwa semakin baik pembinaan di dalam organisasi maka kinerja pegawai akan semakin meningkat.

Hasil penelitian ini sejalan dengan pendapat Mangkunegara (2009:79) mengemukakan bahwa pembinaan merupakan kegiatan yang terstruktur dan terjadual bagi peningkatan kinerja pegawai. Selain itu juga dengan adanya pembinaan diharapkan terjadi peningkatan etos kerja dalam rangka mendukung produktivitas kerja dan profesionalitas, terjadi peningkatan kerjasama antar PNS; dan perlindungan terhadap hak-hak sipil PNS yang pada akhirnya bemuara pada peningkatan dan perbaikan kinerja pegawai itu sendiri.

\section{SIMPULAN}

Berdasarkan dari hasil penelitian tentang Pengaruh Pembinaan dan Pengembangan karir terhadap Kinerja pegawai Dinas Ketahanan Pangan, Pertanian dan Perikanan Kota Banjar, maka dapat peneliti simpulkan sebagaiberikut :

1. Pembinaan cenderung sedang dan kinerja pegawai juga cenderung sedang, dengan demikian pembinaan berpengaruh positif terhadap kinerja pegawai dengan tingkat keberpengaruhan yang cukup kuat, artinya semakin baik pembinaan (disiplin, karir, dan kode etik profesi) di dalam organisasi maka kinerja pegawai akan semakin meningkat.

2. Pengembangan karir cenderung sedang dan kinerja pegawai juga cenderung sedang namun mengalami peningkatan, dengan demikian pengembangan karir berpengaruh positif terhadap kinerja 


$\begin{array}{lrrlr}\text { pegawai } & \text { dengan } & \text { tingkat } & \text { Malang). Jurnal } & \text { Administrasi } \\ \text { keberpengaruhan } & \text { yang } & \text { cukup kuat, } & \text { Bisnis, 8(1). } & \end{array}$

artinya apabila pengembangan karir dilakukan lebih baik, lebih jelas dan lebih kuat maka kinerja pegawai semakin meningkat pula.

3. Pembinaan dan pengembangan karir memiliki pengaruh yang positif terhadap kinerja pegawai dengan tingkat keberpengaruhan yang kuat, artinya semakin baik pembinaan dan pengembangan karir maka kinerja pegawai akan semakin meningkat.

\section{DAFTAR PUSTAKA}

Bungin, B. (2007). Analisis data penelitian kualitatif. PT Raja Grafindo Persada..

Bungin, P. D. H. B., \& Sos, S. (2005). Metodologi penelitian kuantitatif. Kencana.

Darna, N., Rosliyati, A., \& Herlina, E. (2015, May). The Implementation of Controlling, Coaching and Counseling; For solving corruption problem in Indonesia. In International Conference on Economics and Banking (iceb-15). Atlantis Press.

Harlie, M. (2012). Pengaruh Disiplin Kerja, Motivasi dan Pengembangan Karier terhadap Kinerja Pegawai Negeri Sipil pada Pemerintah Kabupaten Tabalong di Tanjung Kalimantan Selatan. Jurnal Aplikasi Manajemen, 10(4), 860-867.

Mangkunegara, A. P., \& Prabu, A. (2003). Perencanaan dan pengembangan sumber daya manusia. Bandung: Refika Aditama.

Munir, A. S. (1994). Pendekatan Manusiawi dan Organiasi terhadap Pembinaan Pegawai. Jakarta: PT. Toko Gunung Agung.

Sudiro, A. (2011). Perencanaan Sumber Daya Manusia.

Wahyuni, D. (2014). Pengaruh Pengembangan Karier Terhadap Prestasi Kerja Karyawan (Studi pada Karyawan Tetap PT. Astra International, Tbk Daihatsu 